\title{
CURRENT DECENTRALISATION ISSUES ON SUB-CENTRAL GOVERNMENT LEVELS IN OECD COUNTRIES
}

\begin{abstract}
Summary
After the economic crisis of 2008, local governments performed crisis management on their own since central governments' actions restricted individual local government actions in most countries. Thus, local policy actions brought significant results only later. In the second period - after 2011 - local government policy actions helped to overcome the negative effects of the crisis and - in some cases paved the way for the modernisation of the local government system. This became a central issue for countries since ageing of population, shifting within the demand of local public goods and inefficient operation called for structural changes.

Modernisation of local public system is a complex phenomenon and reaches far beyond the scope of this paper thus we make an attempt to summarize the general state of local decentralisation after 2008 , introduce some new theoretical findings of OECD's researches and its positive implications in member states.

We argue that diverse national policy changes do not support widescale comparisons but pioneers of local government reforms will gain the most benefits of modernisation. Local government systems shall - very soon - not only bear the burden of central governments' task and revenue sharing issues but more and more incorporate long term sustainable correlations with the educational system and local economic development - probably the most effective tools for raising competitiveness at the sub-central level.
\end{abstract}

Keywords: fiscal decentralisation, sub-central governments, crisis, local development

\section{Introduction - Local crisis management in OECD countries}

The economic depression of 2008 had a serious effect on OECD countries' state budget. Recent papers admit that sub-prime crisis was only a peak of a deeper structural imbalance on national economies. In order to handle the crisis, member states performed a widescale rescue program, embracing banking sector, corporate sector and state budget as well [Kovács - Halmosi 2012, Halmosi 2014]. Although one shall believe that the crisis was mainly present at the central level we argue that both central and sub-central levels faced serious problems. OECD-wide, the general government deficit rose from 1\% of

\footnotetext{
1 Associate professor Peter Halmosi - Faculty of Economics and Business Administration, University of Szeged; e-mail: halmosi@eco.u-szeged.hu.
} 
GDP in 2007 to $8 \%$ in 2009 before going back to $6 \%$ in 2012. As for sub-central governments' balance sheets, they were close to balance in 2007 but then slumped to a deficit around $2 \%$ before recovering in 2012.

Central governments' crisis management actions were rather occurrent in the meaning that governments used widescale crisis management actions - e.g. curbing of state budget expenditures, increase and decrease of taxes, extensive capital market borrowing transactions, bail-out actions, stimulus programs. These actions gained only short term and moderate results between 2008 and 2011. We argue that a completely new phase had been launched in 2011 with more targeted and precise crisis management actions and steps by central governments. Improvements of sectoral crises management of central governments supported sub-central governments crises management actions. This would become a cornerstone how and what extent sub-central governments can gain economic results. Fiscal consolidations have been usually started earlier at the local level in OECD countries, however, intergovernmental task and revenue assignment issues can be both supportive or restraining factors. We argue that sub-central governments that were not let alone but involved deeply in crisis management and task and revenue assignments were established accordingly would get the most benefit later on.

FIGURE 1.

\section{Central and sub-central government financial position}

A. State level

- - Upper quintile

Net lending, \% of GDP

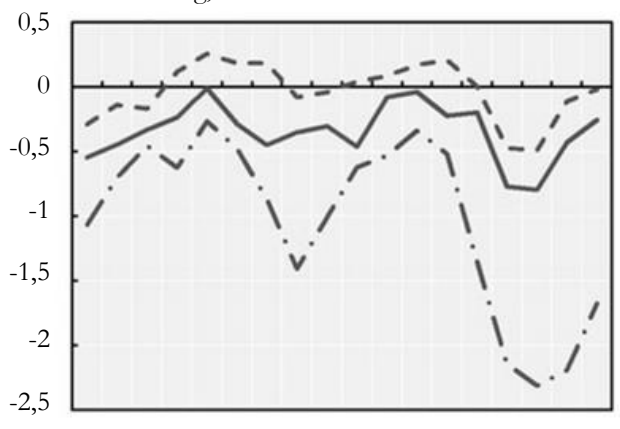

느응
B. Local level Median — - Lower quintile

Net lending, $\%$ of GDP

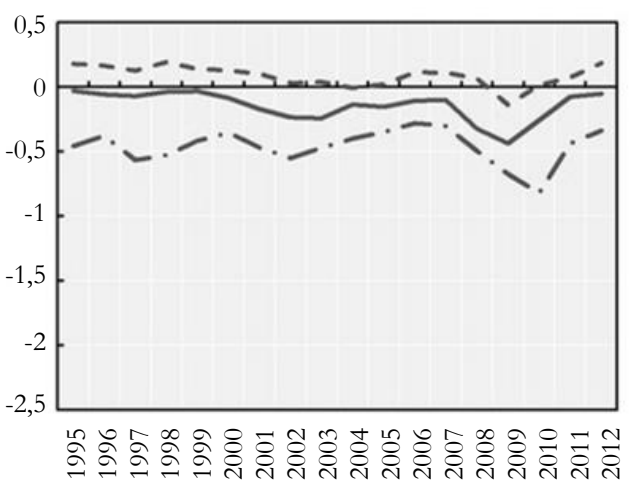

Source: [OECD, 2013, p. 12].

The recent crisis distinguished financial capacities of sub-central governments in all countries. During prosperity, high and low risk sub-central units have a better chance for borrowing which is a very important tool to smooth operation. Figure 1 shows that during the crises of mid 1990s and of 2008, central governments net lending was much different from sub-central governments on average in OECD countries. This suggests different financial capabilities but temporary intergovernmental conflicts as well. 
During the crisis, credit flows to sub-central governments perceived as risky were temporarily disrupted. In-contrast, top-rated sub-central governments benefited from a flight to quality and continued to tap into international bond markets without any major difficulties. "Yields from high-quality and highly-rated bonds were lower in 2012 than in 2007 while yields from those of less-creditworthy sub-central governments reached record highs" [OECD 2013]. Finally, certain units gained extra benefits from cheap and unlimited credit flows while certain units faced more serious operational problems.

OECD-wide the moderating of local spending became also of paramount importance since down grading of debt or only the suspicion about the unsustainability of debt could change the judgement of sub-central governments on capital markets. Local debt creates externality among sub-central governments which calls for a joint action of local and central level. Occuring types of externalities regarding indebtedness can be the following [OECD 2013]:

- Descending externalities: debt dynamics at the central level may affect subcentral units by increasing interest rates and debt service costs.

- Ascending externalities: sub-central debt dynamics can get central government into trouble. In case of implicit central government guarantees upon local debt bail-out of localities may affect the sustainability of central debt.

- Horizontal externalities: Fiscal problems of a few sub-central governments may spread to all. Bankruptcy or insolvency may affect sustainability of all debt.

These externalities were especially present in less developed OECD countries (Hungary, the Czech Republic, Estonia) but also where previously high level of debt was exacerbated (Italy, Spain, Greece) As can be seen from above, there is a high symbiosis within the state budget among central and sub-central levels. In the following chapter we summarize sub-central financial situations after 2008.

\section{Evaluation of sub-central governments' performance after 2008}

A deep analysis of local government status reaches far beyond this paper so here we pick only the most important facts. Again, countries' specific tendencies and general tendencies shall be investigated together:

- In the time of crisis, local budget deficits were greater at the sub-central level than at the central level, and the sector moved slowly towards equilibrium [Halmosi, 2013]. In other words, on the side of public finances, it was the sector itself that represented a barrier to recovery from the crises.

- The budget balance position of the local level increased drastically in 2008-2009, with deficit between 0.3-1.1 per cent of the GDP in most countries, which at the same time, started showing significant decrease as of 2010-2011.

- In this period, due to improving their own budgetary positions, central governments typically considered the budget deficit of the local level a secondary problem area. However, over the course of a few years, the process had changed as the quality of local public services had to be maintained, partly because 
serious concerns surfaced regarding the - uncontrollable - long-term indebtedness of the local level.

- Between 1995 and 2008, the expenditures of the local government level within total government expenditures increased from 31 to 33 percent in OECD countries, while the ratio of local revenues within total government revenues grew from 16 to 17 per cent [OECD 2012].

- A significant increase in local government debt was observed in certain countries: the debt of Austria, Denmark, Finland, Hungary, Norway, Slovakia and Spain, measured in GDP, increased by 2-3 percentage points on average, however, a varied picture may be observed in the case of the individual countries. In addition to the deterioration of the general financial situation of Latvia, Romania, Slovenia, Hungary and Slovakia, the significant increase in deficit, therefore debt as well, is also closely related to the appearance of structural support.

After the outbreak of the crisis, debts increased outstandingly in countries where the creditworthiness of local governments was previously high and borrowing was not strictly restricted. The important lesson here is that borrowing regulations should not only cover the method and rate of borrowing in the future, but the management of insolvency as well.

Crises management affecting sub-central governments occured in the following ways:

- Intergovernmental task and revenue assignments. Measurements included the modification of intergovernmental transfers, regulation of sub-central borrowing and debt, decentralisation and recentralisation of public tasks.

- Local actions. Measurements included direct budget interventions (revenue and expenditure actions) local labour market interventions, local investment regulations and restructuring of public service provision.

Both empirical and comparative studies have been prepared about the effect of the crises on sub-central governments and the efficiency of sub-central policy actions. Nonetheless, results are in most cases unfortunatelly mismatching with each other. We argue however for the following based upon these researches:

- Managing sub-central government crises requires a symbiosis with central government level crisis management. However, there are no best techniques or advices yet how to achieve this goal. Lack of long term planning and constant reform constraint of state budget - among others - make this goal currently inaccessible.

- Reforming tasks and revenue assignment is important to avoid major structural problems but will definitely push few sub-central units in an even deeper crisis.

- Typical and traditional crisis management actions (e.g. local labour market interventions) lack of real power. Countries with a high number of small localities have more structural problems in crises since there are is no chance for a prompt success. Framework regulations (e.g. financial compensatory regulation in Austria, mid-term local planning in Norway supported by the central governments' professional units like State Audit Offices) filled up with content may however build up long term sustainable features also in small localities. 
- There are only a few indicators to evaluate and compare the effect of completely different actions. At this point we recognize the OECD's effort in establishing new evaluation criteria (see below).

\section{The OECD's Synthethic Fiscal Rule Indicators}

Since 2005, the OECD has prepared new fiscal rule indicators, which provide a composite assessment of Member State regulations along the following dimensions: limiting sector size through constraining expenditure growth, assuring allocative efficiency, achieving debt and deficit sustainability and dealing with economic shocks. This set of indicator has the following benefits:

- evaluation of changes and their interactions in different fields of sub-central policy actions in countries;

- comparison of sub-central policy action among countries; This is important since local public finance system is totally different in all countries and are so hardly comparable with each other.

- $\quad$ direct actions aimed at meeting complex government policy targets (low level indicators are comprised into sub-indices).

\section{OECD's fiscal rule indicator}

FIGURE 2.

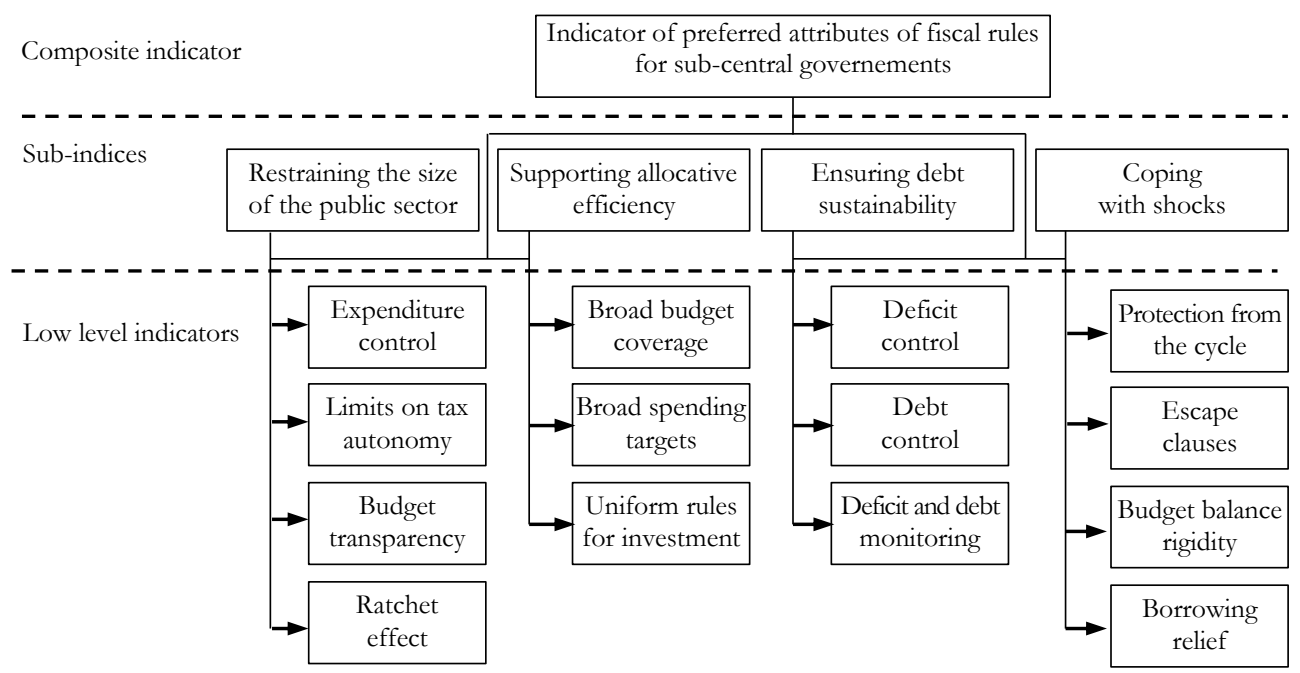

Source: [OECD, 2011, p. 48].

The fiscal rule indicators serve as tools of synthesising several rules affecting the budget of local governments, as in some cases, national rules regarding the limitation on 
borrowing, tax autonomy and restricting expenditures are complemented by material conditions in certain countries, the aggregate effect of which should be examined.

Though the OECD only prepared the composite indicator for two years, 2005 and $2011^{2}$, the impact of the economic crisis on government approach is noticeable. In the period under review, none of the countries managed to control efficiently the increase of the local government level, in other words, the widening and deepening of local needs contributed to the sector increasing. Slight deterioration was observed in improving allocative efficiency at the local level in several countries (Finland, Poland, Austria), but there are also some countries that have managed to improve (Norway, Czech Republic, Spain, Germany). Examining the measures taken with respect to sustaining the budget deficit and public debt, considerable deterioration was observed in the Czech Republic and the Netherlands, however, improvement was recorded in Finland, Germany, Norway and Spain. Finally, the last composite indicator of the OECD, the indicator of the ability to cope with economic shocks showed deterioration in all countries, especially in Estonia, Poland, Slovenia and Spain, where the values calculated were close to minimal.

A recent paper of OECD revealed country specific evaluation of sub-indices (Figure 3).

FIGURE 3.

\section{Sub-indices of OECD fiscal rule indicator}

Panel A. Expenditure control

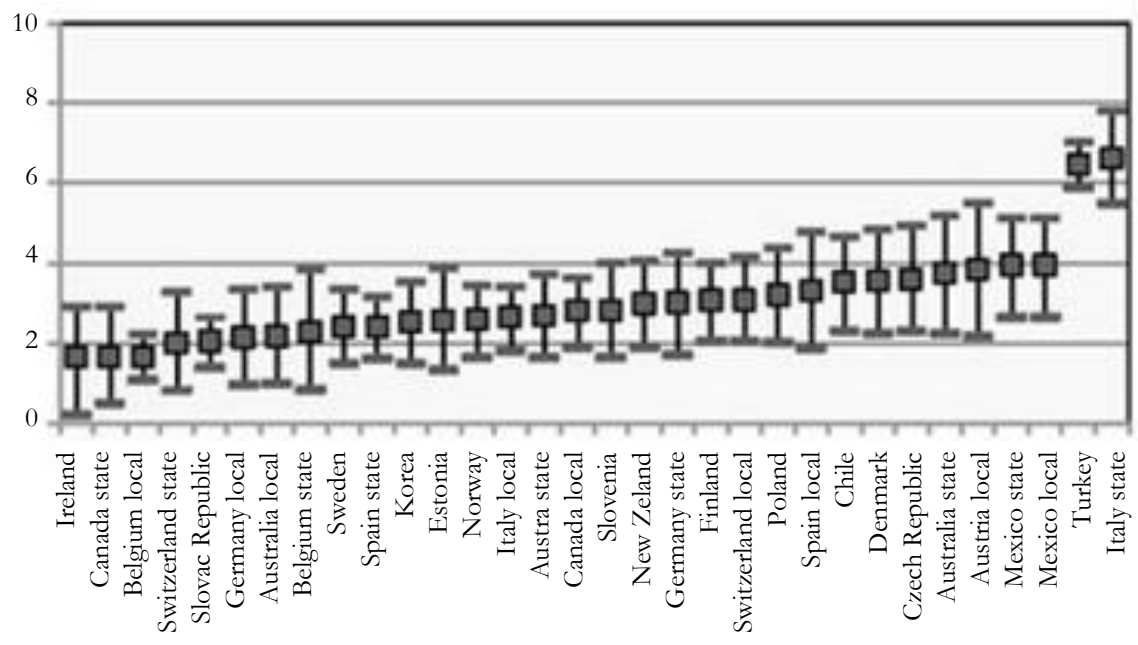

2 Investigated countries are: Australia, Austria, Belgium, Canada, Chile, the Czech Republic, Denmark, Estonia, Finland, Germany, Ireland, Italy, Korea, Mexico, New Zealand, Norway, Poland, Slovak Republik, Slovenia, Spain, Sweden, Switzerland and Turkey. 


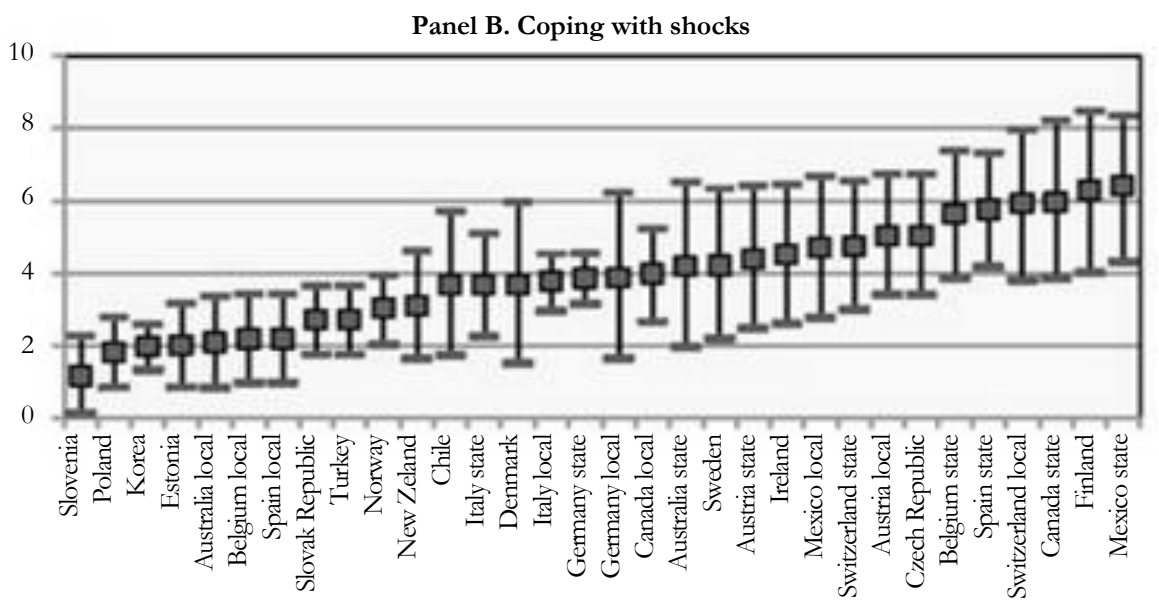

Panel C. Allocative efficiency

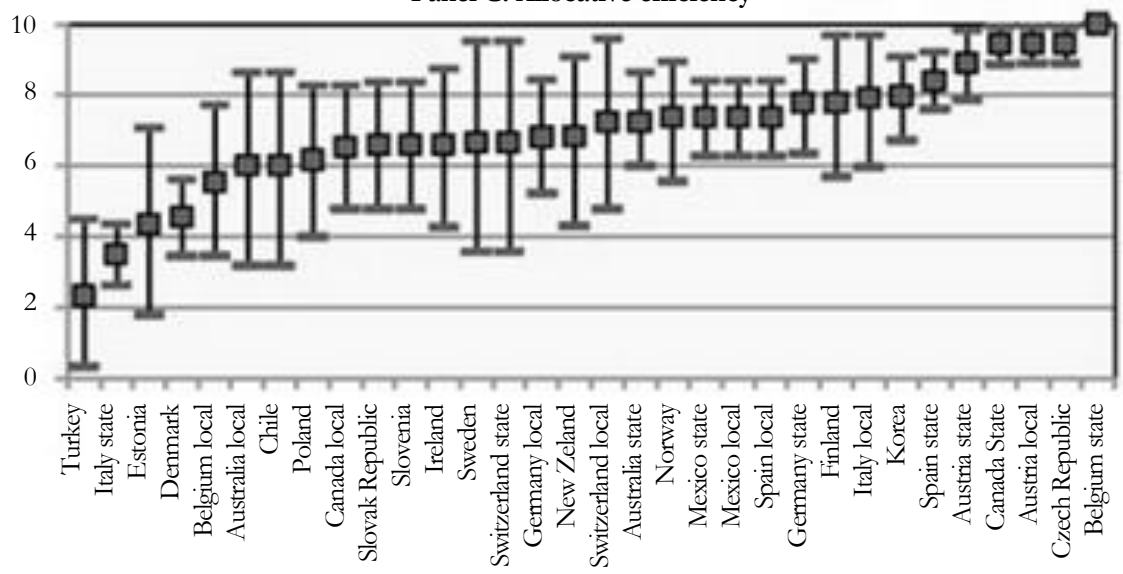

Panel D. Sustainability

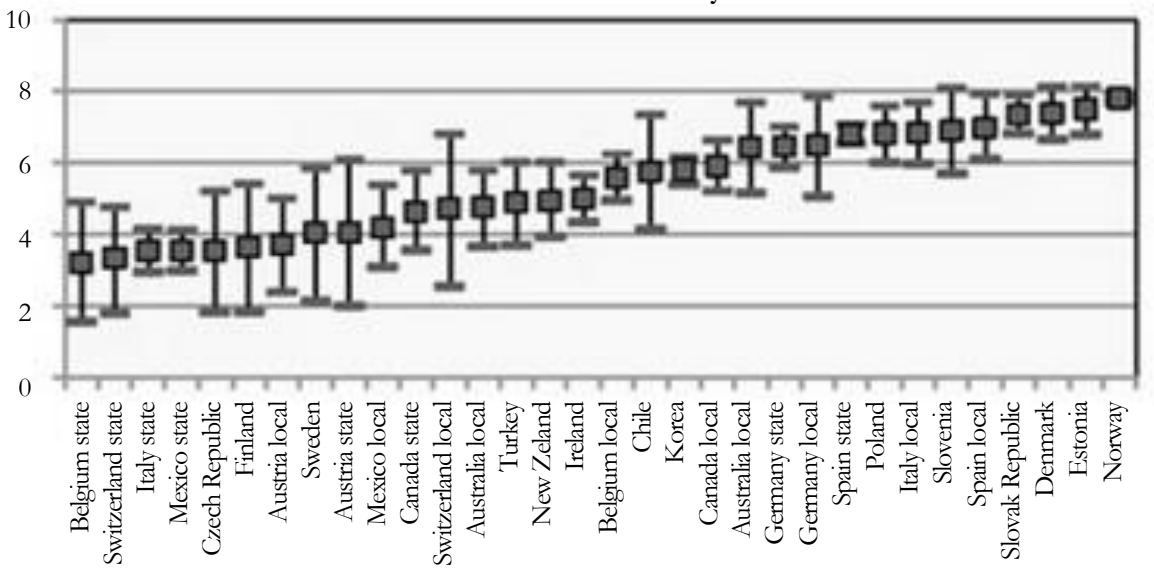

Source: [OECD, 2011, p. 50]. 
Countries having a better position in allocative efficiency are in a much better position when reforming the educational system and the same is the case with the position in sustainability and local development issues.

\section{Economic development at sub-central level - policy considerations for reformers}

Recent studies of OECD revealed that there is small but positive correlation between decentralisation and GDP per capita growth however no real connection has been so far observed with investments in general.

According to Solow, economic activity depends on factors like physical assets, population, technology level and recently on policy considerations. We believe that decentralisation of the government sector is a policy consideration, what's more: it is the location of public sector innovation itself.

Empirically: raising sub-central governments' revenue from 15\% to $30 \%$ would increase per capita GDP by 3\%. Blöchliger et al. [2013] revealed that improvement of productivity and human capital lie behind this. There is a significant deflection among federal and unitary states but also in the way sub-central revenue growth is derived from:

- extension of sub-central borrowing is rather dangerous for local growth,

- further intergovernmental transfers have moderate effects (see „flypapereffect),

- $\quad$ local revenue raising (e.g. local taxes) may have an impact on local growth.

Real correlation can be found in case of tax policy considerations. Previous researches found that both tax increases and decreases can support local growth. The former supported the growth by short term stimulus while the latter supported it by long term stimulus. Sub-central governments may either offer tax exemption in order to perform investments or perform investment on their own - in this case by tax raising. The key point is: will investments perform economic growth or not? This is related to policymakers' decision which cannot be generally put in a mere public finance theory. Performing investments needed by the local economy in a good cooperation of public and private sector can bring economic growth. To sum up, tax policy is a good tool but it will not bring results on their own. Decentralisation is not a general "medicine" for the health status of the local economy.

\section{Educational system changes at sub-central level - policy considerations for reformers}

Education is an important well-being task of sub-central governments in OECD countries, however, there are significant differences in revenues and tasks. Like most well-being tasks, education is shared between the central and sub-central governments bearing new and new conflicts: 
- Sub-central governments are involved in performing primary, secondary, postsecondary school education, however, they are repsonsible mainly for operation.

- Geograpchic conteaxt of education is very important. Boundaries, urban and rural distinctions call for a special collaboration between sub-central and central government level. There would be a great need for precise sharing of tasks and responsibilities however it is not reached in most contries.

- However precise tasks can be defined and shared among tiers of government, financing is performed on an annual budget principles. There are changes in normative financing so it is usually not a matter of course how schools - that eventually provide services - will be financed in mid-term. This has a tangible effect ont he quality of local education.

In some countries, the funding of education is centralised; in others, funding can become decentralised after transfers among the different levels of government. In recent years, many schools have become more autonomous and decentralised organisations; they have also become more accountable to students, parents and the public at large for their outcomes. The results from the OECD Programme for International Student Assessment (PISA) suggest that when autonomy and accountability are intelligently combined, they tend to be associated with better student performance [OECD, 2014, p. 254].

FIGURE 4.

Change in the proportion of educational funds received from the different levels of government between initial and final purchasers of educational resources, at the primary, secondary and post-secondary non-tertiary levels (2011) in percentage points

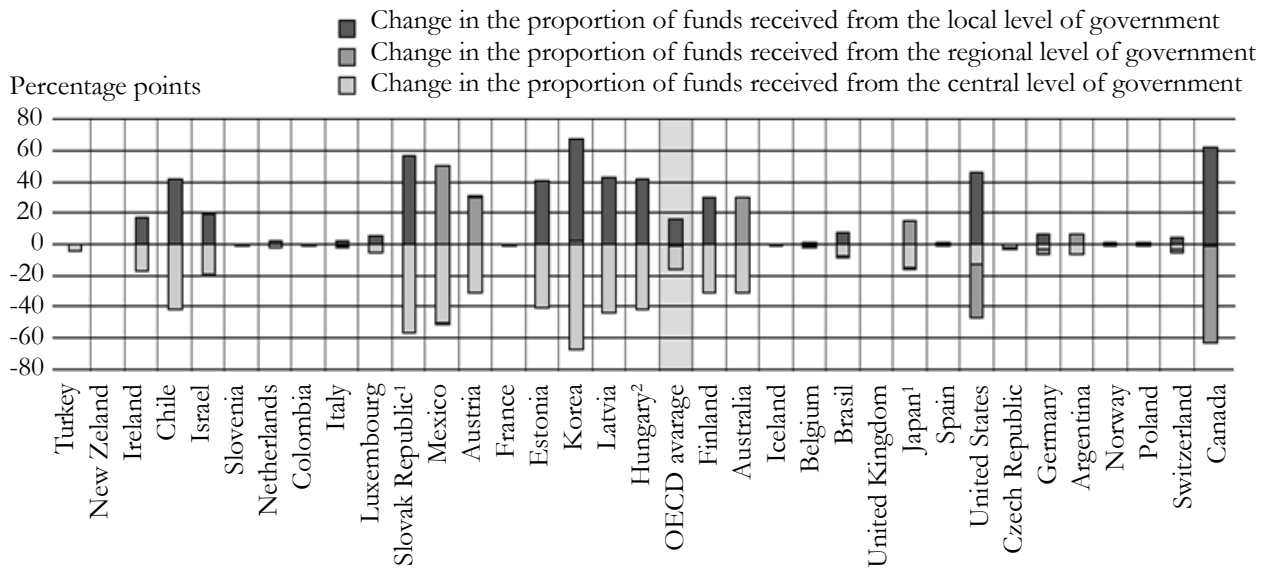

1. Some levels of education are included with others. 2. Funds from the local level include funds from regional level of government.

Source: [OECD, 2014, p. 255]. 
Recent studies however revealed that increasing decentralisation creates an extra financial flow to education. A $10 \%$ of decentralisation increased PISA scores by 4 points and improved the countries' ranking by 4 position. We believe that increasing spending on education can be considered as investment and so having positive effect on the region. In case of education, territorial differences support competition among educational institutions being providers. Beneficials prefer to be closer to decisions on content of education and this will also increase transparency and efficiency. Higher efficiency comes partly from higher quality of education (e. g. higher motivation of teachers, better circumstances for education).

We admit that improving quality of education focusing on local government level is rather restricted, but, it is important to be clear with the possibilities. Policy makers will thus consider changes which can be groupped as follows:

- $\quad$ organisation of instruction (e.g. curriculum content, teaching methods);

- personnal management (e.g. hiring of staff, responsibilities);

- planning and structure (e.g. defining course content, monitoring school performance);

- financial resources (e.g. allocation of budget, development of school improvement plans).

Power delegation to sub-central levels should however be targeted to the subcentral policy level and not to schools. This can be considered as part of a wide-range policy reform while delegating more power to schools can be observed only if quality of service is at danger.

FIGURE 5.

Correlation between lower level government decentralisation and school

School Autonomy indicator, 2009 autonomy

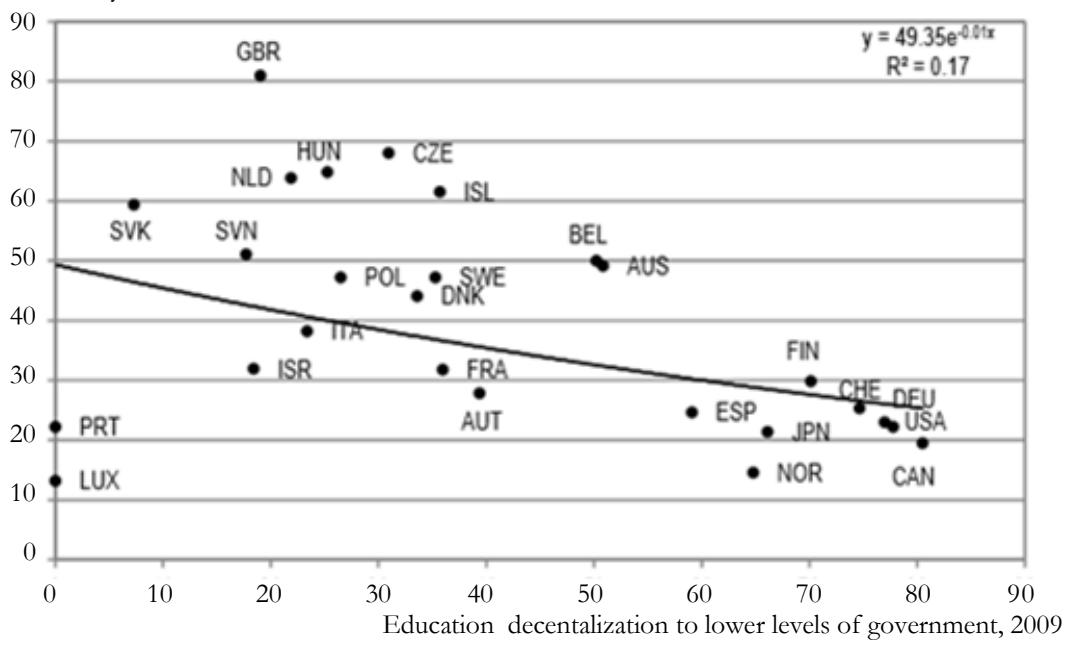

Source: [Fredriksen, 2013, p. 14]. 
Policymakers shall consider further decentralisation of education to sub-central levels. Reforms must keep strong control within the central government but quality related issues - especially those with high incentives and motivation - shall be professionally investigated and changed. Reform indicators can be further supported by better local economic development achievements.

\section{Conclusions}

In 2008, global crises hit not only the central government, the corporate sector and the banking sector but the sub-central government sector as well. After 2011, central government crises management paved the way for targeted sub-central government crisis management. This became importand since central and sub-central financial health is strongly correlated by externalities.

Sub-central governments improved their budget status and commenced with reforms after 2011. The crises, however, distinguished financial capacities of sub-central governments in all countries. Certain units gained extra benefits from cheap and unlimited credit flows while certain units faced more serious operational problems. Both empirical and comparative studies have been prepared about the effect of the crisis on sub-central governments and the efficiency of sub-central policy actions. Nonetheless, results are in most cases unfortunatelly mismatching with each other. Thus, the OECD synthetic fiscal rule indicator is an important tool to evaluate policy action effects.

Indicators are important since reforms change the system as a whole. Recent findings on local development and education policy actions support decentralisation of sub-central systems but professional decisions. We argue that sub-central governments shall be vested with more powers in economic development and education system but a good cooperation of public and private sector is indispensable.

We argue that crises management at sub-central levels shall in the future be more targeted, since there are no general techniques. A new dimension of intergovernmental cooperation and its decent measurement and evaluation is also essential since - based on current decentralisation issues - most information can only be analysed in their deep contexts.

\section{References}

Blöchliger H., Égert B. 2013 Decentralisation and Economic Growth - Part 2: The Impact on Economic Activity, Productivity and Investment, "OECD Working Papers on Fiscal Federalism", No. 15, http://dx.doi.org/10.1787/5k4559gp7pzw-en, retrived: 08.14.2014.

Fredriksen K. 2013 Decentralisation and Economic Growth - Part 3: Decentralisation, Infrastructure Investment and Educational Performance, "OECD Working Papers on Fiscal Federalism”, No. 16, http://dx.doi.org/10.1787/5k4559gg7wlw-en, retrived: 08.14.2014.

Halmosi P. 2013 The Effect of the Economic Crisis on Local Government in OECD Countries, "Public Finance Quarterly", Vol. 58, No. 3, pp. 293-306, http://www.asz.hu/ 
en/public-finance-quarterly-articles/2013/the-effect-of-the-economic-crisis-onlocal-governments-in-oecd-countries-1, retrieved: 01.10.2013.

Halmosi P. 2014 Results and Doubts of Economic Crisis Management, "Magyar Tudomány", No. 2, pp. 151-162.

Kovács Á., Halmosi P. 2012 Similarities and Differences in European Crises Management, "Public Finance Quarterly", No. 1, pp. 9-27.

OECD 2011 Fiscal Rules for Sub-Central Governments - 2011 update of the OECD indicator, http://www.oecd.org/eco/public-finance/Fiscalrulesforsub-centralgovernments 2011 updateoftheOECDindicator.pdf, retrived: 08.14.2014.

OECD 2012 Reforming Fiscal Federalism and Local Government. Beyond the Zero-Sum Game, “OECD fiscal federalism studies", http://dx.doi.org/10.1787/9789264119970-en, retrived: 07.04.2014.

OECD 2013 Fiscal Decentralisation 2014: Making Decentralisation Work, OECD Publishing, http://dx.doi.org/10.1787/9789264204577-en, retrived: 07.04.2014.

OECD/Korea Institute of Public Finance 2013 Measuring Fiscal Decentralisation: Concepts, policies, OECD Fiscal Studies, http://dx.doi.org/10.1787/9789264174849-en, retrived: 08.14.2014.

OECD 2014 Education at a Glance 2014: OECD Indicators, OECD Publishing, http://dx.doi.org/10.1787/eag-2014-en, retrived: 08.24.2015. 